\title{
The potential of food terrorism towards halal ecosystem
}

\author{
${ }^{1}$ Abd Razak, M.A., ${ }^{1}$ Ramli, M.A. and ${ }^{2}$ Jamaludin, M.A. \\ ${ }^{1}$ Department of Fiqh and Usul, Academy of Islamic Studies University of Malaya (APIUM) \\ 50607 Kuala Lumpur, Malaysia \\ ${ }^{2}$ International Institute for Halal Research and Training (INHART), Level 3, KICT Building, International \\ Islamic University of Malaysia (IIUM), 50728 Kuala Lumpur, Malaysia
}

\author{
Article history: \\ Received: 9 August 2019 \\ Received in revised form: 30 \\ November 2019 \\ Accepted: 1 January 2020 \\ Available Online: 10 \\ February 2020
}

\section{Keywords:}

Food protection,

Food defence,

Food supply chain,

Food terrorism,

Halal ecosystem

\section{DOI:}

https://doi.org/10.26656/fr.2017.4(S1).S19

\begin{abstract}
The approaching of megatrend 2050, challenges have emerged in the food sector and it is predicted that main issues would be the shortage of food supply and food contamination. In parallel to the Food and Agricultural Organization (FAO), that by 2050, with the increasing human population, the food supply would be affected as the sources are inadequate to cater. This crisis requires a comprehensive solution - necessitate a better food security policy, food safety and food defence. In other words, a focused policy that deals with safe food ecosystem must be implemented and strengthen by relevant authorities. In the Malaysian context, the National Safety Policy (2017) outlined the security assurance for the nation's food supply under Strategy 17. However, the focus of the policy is only on the preparedness of rice commodity that needs to be adequate, whereas, newer threats is making their way beyond that scope. Therefore, this review will discuss the potential of food terrorism, its concept and implication within the halal ecosystem. To achieve this objective, this study is qualitatively carried out by utilizing fully library research relating to food terrorism. The data is being analysed to conclude the findings. Based on the study, we found that food terrorism is indeed a real threat jeopardizing consumer safety, and moreover, causing negative implications towards the local, regional and global halal ecosystem. Therefore, proactive measures needed to be taken to ensure the security of food and this aligned with the objective of sharia to preserve human's life by having adequate, nutritious, halal and safe food.
\end{abstract}

\section{Introduction}

Food is vital for life. Without food supply, any life form, particularly human will encounter devastating impacts such as malnutrition and famine and even death. On the other hand, imbalance of food intake will lead to negative effects such as obesity and the risk of chronic diseases. Adequacy of food supply with a balance food intake is part of the larger Islamic teaching of halalan toyyiban concept. This concept outlined the Islamic perspective of food ethics and offers bodily strength (by eating good food) as well as spiritual goodness.

In reality, halal food production faces many threats of which affects its halalan toyyiban integrity, which is: halal-haram of food and food safety. These threats include food contamination within the food supply chain, be it intentional or non-intentional. The act of intentional contamination may be classified as food crime that intended to gain profit or, the orientation of using food as an act of terror that intended to utter destruction, chaos and panic among consumers at large.

All of these acts of contamination brings harmful effects towards consumers both in short and long term, and it could severely cause damage to public health and may cause death. In a broader picture, these threats potentially disrupt the development of the local, regional and global halal ecosystem. According to (Dalziel, 2009), cases of malicious contamination within food supply chain from 1951-2008 recorded a total of 391 fatalities and 4,355 injuries. It is estimated that on average, there are 6 incidents per year with 7 deaths and 75 injuries occurred due to this threat. Based on the record, cases of food malicious threat recorded in 1999 ( 1 case) and in 2005 ( 2 cases). This record shows that the potential risk of having malicious attacks on food arrived in Malaysia.

Recently, the cases of chemical contamination of 
water supply in Sungai Kim Kim in the state of Johor have put the nation to unrest (Yusof, 2019). Within a few months later it is reported that the neighbouring area, Pasir Gudang put many local schools to be shut as the air is polluted with an unknown chemical. Though these cases may fall into the deliberate release of chemical to the environment, the situation and circumstances can be the starting point for food protection against malicious threats in Malaysia, as the effect can be more severe and devastating. The United States has foreseen the threats prompted Food Safety Modernization Act (FSMA) signed by President Barrack Obama in 2011 giving to the new scope of safe food protection and authority to Food and Drug Administration (FDA) (FDA, 2019). Therefore, the aim of this paper is to present the threat of malicious food contamination, particularly food terrorism towards the halal ecosystem.

\section{Emerging threats in global food supply chain}

In today's world, the act of terrorism has risen with the advancement of technology. It started from traditional to newer form, such as cyber-terrorism, bioterrorism and food terrorism. Food terrorism is defined by World Health Organization (WHO) as: "an act or threat of deliberate contamination of food for human consumption with chemical, biological, or radionuclear agents for the purpose of causing injury or death to civilian populations and/or disrupting social, economic or political stability." (Ereifej, 2011). In other words, it refers to intentional contamination towards several components of the food supply chain with the motive of bringing harmful effect physically or economically and create fear and terror.

Food is one of the targets which is used to incite prolong fear with the imaginary of danger in future which involved the whole world (Kinsey et al., 2009). Food terrorism is not much different from food safety as they both share the same types of threats: chemical, biological, physical, radio-nuclear, and allergens (Food Act 1983, 2018). The difference between the two can be distinguished from the motivation, i.e. ideology (for food terrorism), whereas food safety issue largely deals with unintentional contamination rather than intentional.

Food terrorism involved malicious attacks upon food sources, especially agricultural sources in form of agroterrorism or bioterrorism. CATRC (2010) defined agroterrorism as: "Act of destruction towards whole agricultural system including infrastructure, input, process and product intended to harm domestic and international interest of the targeted nation, and for the political interest of the attacker." The reasons of agroterrorism act are the intention to alter and interfere with the food supply chain to fulfil demands of a certain commodity. This will create a serious economic burden of the political enemy (Caldasa and Perz, 2013).

An attack of food terrorism in terms of the food supply chain may affect almost every part of the chain, starting from raw materials until it reaches the hands of the consumer. This includes cattle or farmed animal, dairy products, food products within the processing chain, distribution, retails, warehousing, transportation and crops. The agricultural sector of all nations is vulnerable to terror threats. For example, the usage of poisonous additive with the intention to disrupt planted crops or farmed animals. These agents can be put at any level within the agricultural infrastructure in which become the main source of food to the consumer. The implication of such action will cause serious illness, death, economic loss either direct or indirectly (Rohn and Erez, 2013).

\section{The concept of food terrorism}

The term 'food terrorism' is relatively new and was popularized after the incident of 9/11 attacks. Nevertheless, according to literature, the practice and severity of food terrorism can be seen in the history of mankind. In 2002, the WHO published a guidebook entitled: Food Safety Issues: Terrorist Threats to Food became one of the earliest references for food terrorism. WHO has defined food terrorism as an act or threat of deliberate contamination of food for human consumption with chemical, biological or radio nuclear agents for the purpose of causing injury or death to civilian populations and/or disrupting social, economic or political stability. In our view, this is the most elaborate and precise definition and thus will be the reference for this paper. The guidebook is an effort to promote state member to beef up existing food safety programme in particular deliberate acts of sabotage of food.

The practice of using food as a tool for spreading terror amongst people is nothing new in history. In medieval times, this practice of military campaign is implemented as one strategy to weaken the enemy's position beside conventional weapons. This includes poisoning the water supply and food source to stir panic, terror and even death among the civil population. Food terrorism is closely related to bioterrorism and agroterrorism and this will be discussed later in this paper. Food terrorism is a vital part of food defence, a concept that becomes the umbrella concept that covers food crime and food terrorism. Most of the literature found are more focused on food defence and food terrorism is mentioned as part of that bigger concept. According to Mitenius et al. (2014), global terrorist 
threat on the food supply chain can be a major threat and more tragic than the conventional attacks. Interestingly, they argued that there is no confirmed evidence to date that global terrorist groups have executed an actual attack against the food supply, although such events have aroused suspicion.

One of the most profound literature regarding food terrorism is presented by Davidson, et al. (2017). In their research, they study on the effectiveness of food defence methods to mitigate deliberate attacks on the food supply chain. They also highlighted that the incidents of deliberate attacks on food can severely affect consumer's confidence and this is proven when the European food industry was shaken due to scandals for example, the 2013 horsemeat scandal, aflatoxin-contaminated milk and foodborne disease outbreaks. Davidson et al. (2017) also listed down terminologies that differentiate the term 'food terrorism' with other related concepts such as food security, food safety, food adulteration, food contamination, food crime, food fraud and many more. Another profound research is carried out by Manning (2019). In this research, Manning presented a taxonomy of food defence and perpetrators supported with the events case study. Manning (2019) suggested that although the cases are fitting with 'food terrorism' elements but not disclosed as so, she emphasised that the threats of food terrorism are a real threat. Manning also precisely elaborate the relationship between food terrorism with agroterrorism and bioterrorism, and for the purpose of this article, we found that it is convenient to say that bioterrorism and agroterrorism is a subset of food terrorism domain. The taxonomy of food protection is illustrated as in Figure 1.

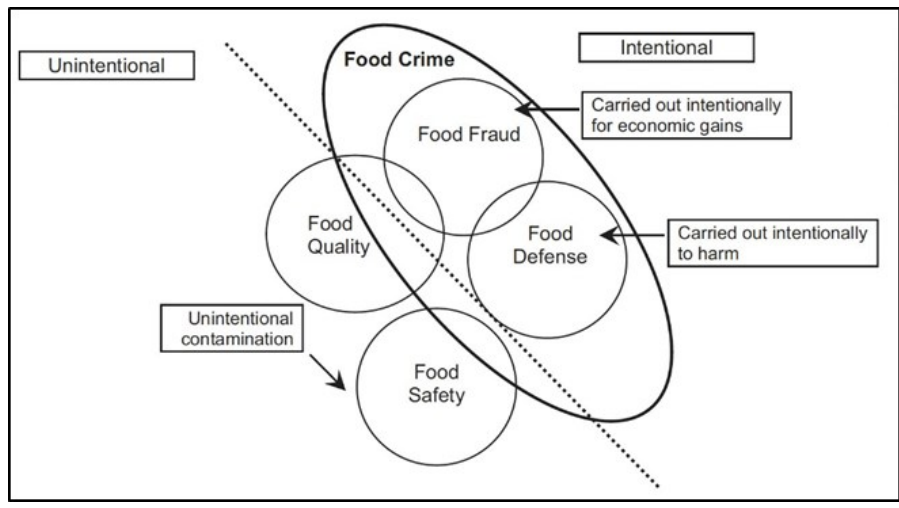

Figure 1. Intentional and unintentional modifications of food (food fraud, defence, safety and quality) (Source: Spink and Moyer, 2011; Manning and Soon, 2016)

From the literature, we found that food terrorism is new emerging topics in food safety and food supply chain discipline. The direction of food safety programme should now moving forward to include food defence as well. Pedersen et al. (2016) concluded that existing food safety analysis is not adequate to protect food as the conventional food safety testing failed to address unusual contaminants that are found to be a deliberate attack on food. To this concern, we presented the potential of food terrorism towards halal food supply chain because they are still a few available dedicated research and resources.

\section{Food terrorism threats within food chain}

Industrial revolution 4.0 offers cutting-edge achievement in technology superiority. And this does not come without any challenges. In terms of food production, today's and the next generation will have to endure newer challenges that would reach to a new level of threats. These threats are vulnerable to life risk threats, mental and physical threats as well as economic threats. This refers to food crime and food terrorism.

According to Beck (1992), the newer generation is deemed as "risk society" when it comes to food chain risk. In other words, this risk is a lot whole new dimension because of its profanity. This profanity characteristic of food threats require long-term countermeasure and the solution should be carried out through the scientific approach. The advancement of technology has made these threats "invisible" and relying on human senses and perception would not suffice. The complexity of food production has become more even complex, and by the means of scientific analysis, this would be able to determine what's inside our food products (Kartheek, 2011).

Based on the historical timeline, it is known that biological and chemical agents have been used maliciously as a war tool and targeting food is no exception. This includes the act of terrorism in the way that these agents are deliberately placed into the food system and water (as an important medium in the most food supply chain) for creating terror and wage war. These threats do not go as time passes by, and the usage of these malicious agents is still far from stopping.

Chemical agent has been known to be utilized to cause death, disabilities and stir disturbance towards targeted population. The chemical agents that are used as a medium for malicious act can range from industrial grade such as sarin, which has been used since the World War 2 to readily available chemical such as pesticide for example the case of extortion in Japan in 1991 (Dalziel, 2009). This type of agents is one of the most favourable methods to reach perpetrators' objective (crime or act of terror) due to its complexity to be identified promptly, odourless, easy to dissolve, stability in food matrices, easily available, require no technical expertise, no purchasing restriction and difficult to be diagnosed as well as treatment. 
According to Das and Kataria (2010), bioterrorism is difficult to be distinguish from natural disease outbreak and could be caused by virtually any pathogenic microorganism. Biological agent which is used to make an attack is also on the list of the favourable method due to its affordability, easily to be shipped across borders and easy to be kept. The civilian population is vulnerable to this agents and they are exposed to be infected (by the means of contamination) by using bacteria, rickettsia, virus, and toxic chemical such as heavy metals, nerve agents, industrial chemical and pesticide (Ereifej, 2011). There are specific criteria on why terrorist or criminal used biological agent as the agent of chaos. Several reasons are preparation does not require sophisticated skillset, small amount with devastating effect, difficult to be traced, the potential for massive terror, difficult to be diagnosed and easily transmitted from human to human (Hansen, 2010).

Historically, biological agents have been used as war purpose. For instance, in 1936, the Imperial Japanese Army has set up a classified experiment during the occupation of Manchuria. Unit 731 is assigned to carry out these underground experimentation on war prisoners with biohazards such as plague agents, anthrax, gangrene gas, typhus and typhoid. The army itself also known to use ceramic bomb that contained infected grains dropped into Chinese cities during 1940, and cause an epidemic death toll (Tucker, 2002).

Furthermore, another case on the list of bioterrorism and biological threats in food is the incident of mad cow's disease (BSE) in beef meat production. BSE, a type of illness that dysfunction nervous system and transmittable to human is found to be contained in more than 187,000 animals in at least 12 countries. Most of the cases are detected in the United Kingdom initially in 1986. BSE can be transmitted to human via consumption of infected beef products and cause a variant disease called vCJD. Almost 200 people have been diagnosed to have vCJD at that time. This issue is seemingly unsettled when in May 2007, report shows an increasing number of vCJD affected people in the United States (Lister and Becker, 2009).

Analysis made by Carus (2001) regarding the usage of biological agent during 1900-1999, there are four known terrorism-related tragedy occurred such as Aum Shinrikyo (1990-1995) which used Bacillus anthracis agent, Botulinum toxin with other pathogens, Rajneeshees (1984), that used Salmonella enterica serovar Typhimurium agent, Dark Harvest (1981) that used Bacillus anthracis and Mau Mau (1950) used agent Synadenium grantii.

Throughout all cases of terrorism, it is undeniable that the awareness to defence against terrorist attack risen after the tragedy of September 11, 2001. This awareness is highly taken by the U.S. Government where every potential threat either biological or chemical agent is monitored including food supply and agriculture. This method would be handier to be executed compared to the conventional method. The fear becomes more prevalent by the emergence of anthrax attack just after the September 11, where the attack was carried out through random mail (White, 2009).

\section{Threats towards halal toyyiban food sustainability in Malaysia}

The issues of food contamination occurred are not limited to local markets, but also the global market sphere. It involved unintentional contamination - of which cause by mishandling in preparation and also, intentional contamination - of which economically driven crime networks that put profit as their main goal; the act of terrorism which intended to disrupt economy stability in bigger scale within the food supply chain. Generally, food contamination and fraud is carried out by perpetrator that involved directly in the chain and have access to food products. This may involve factory operator, food worker or distributor. Whereas food terror act usually carried out by the outsider, of which not routinely have access to the food products (Johnson, 2014).

In Malaysia, cases of food contamination have been reported affecting public health. These reported cases include foodborne illnesses such as vomiting, fever, diarrhoea and even death. Often cases that are reported are food contamination infected with Salmonella spp. (KKM, 2014). These are several cases of biological contamination as well as chemical contamination such as formaldehyde or formalin, boric acid (Ang et al., 2010), found to exist in today's food products. There are also cases of cross-contamination been reported involving porcine DNA in chocolate products which cause perturbation among consumers (Muhamad Afiq and Mohd Anuar, 2018).

A recent case of food contamination was reported by Malaysian Quarantine and Inspection Services (MAQIS) where parasitic worms are found in canned sardine harboured through North Butterworth Container Terminal (NBCT), Penang in $14^{\text {th }}$ May 2018. The worm is claimed to be Anisakis spp. Genus, a zoonotic parasite that can harm human's gastrointestinal system (Kumarrappa, 2018). This promptly caused product recall from all local marketplace.

Another form of threats that resembles food contamination is food adulteration. Everstine et al. 
(2013) has identified that economically motivated adulteration (EMA) as one of the forms of intentional contamination and their ultimate goal is to gain profit by modifying food unethically. Based on their literature in the study, it is found that 137 unique cases since year 1980 within 11 categories of food: fish and seafood (24 incidents), dairy products (15), fruit juice (12), oil and fats (12), grains (11), honey and natural sweeteners (10), spice and extract (8), wine and alcoholic beverages (7), infant formula (5), plant-based proteins (5) and others. It is clear that EMA is one of the most significant threats in food production.

There are also threats in the form of food fraud cases. Many of these cases are involving meat products (Manning et al., 2016), such as meat fakery (Spink and Moyer, 2011), mislabelling of meat products (Chuah et al., 2016) and meat fraud such as beef fraud in sausages, in which ox meat percentage is identified higher than beef itself. Furthermore, there is also mutton fraud such as the case in China which is reported that the meat substitutes were used which originated from rat meats, fox, mink and other meats (Ali et al., 2014).

In terms of halalan toyyiban, there are cases of food contamination which is intentional in both meat and nonmeat products. From the halal aspect, it involved the fakery of halal food with haram counterparts. For example, substitution with beef with pork, the substitution of mutton with dog meat, un-slaughtered meat and their by-products. On the other hand, the toyyiban aspect, various act of contamination committed by the producers, such as substitution of horse meat in beef products (Castle, 2013), infected beef products (such as BSE meat) and also possible, the threat of malicious food. Many of these cases are driven due to economic reason, where the price of beef and mutton is more expensive compared to other meat sources.

Other than that, dangerous chemical such as formalin and aniline has been also used in meat production to prolong shelf-life and beta-agonist hormone (Jeyaletchumi, 2003) for growth, as well as heavy metals, pesticide, fipronil (toxic chemical) that have a long-term effect towards health. The usage of formalin, mainly as a preservative in fish, can lead to heart failure, liver, brain, pancreas, nervous system and kidney (Bansal et al., 2011) and also a risk of cancer.

Food fraud also is involving other non-meat product as well. This includes olives oil. Olive oils often labelled as authentic olive oil, but the real product contains nonolive ingredient as substitution and in many cases, harmful and haram substance. The cases of food fraudulent that uses other ingredients are sharia noncompliance in food production (Nurulhidayah et al.,
2012) such as mixing pork with other meat (mutton and beef) reported across the world due to the fact that pork is much cheaper alternatives and most available compared to other types of meat (Ni'mah et al., 2016).

These are the several cases of halal and haram issues occurred in the market by irresponsible people for the sake of profit ignoring consumer's safety and Muslim's consumer sensitivity. This is against the teaching of Islam where Islam prohibits food that is harmful and also prohibits the act of selling food which is destructive towards oneself.

\section{Implication of food terrorism threats towards halal ecosystem}

The usage of 'ecosystem' terminology has been used by scholars outside the biological domain to explain sustainability. Moore (1999) applied this term into business domain, as he defined as the structure and behaviour of a network of high-tech organizations that share a key technological platform and the ways individual firms can flourish in such environments. This ecological approach is essential in order to maintain a healthy performance of the ecosystem, in this case, business. Therefore, this approach also applicable to explain the halal industry ecosystem. An early account of using the concept of the halal ecosystem can be seen in the work of Hishamuddin (2007). The halal certification process involved the whole supply chain (in this case, food), but halal ecosystem covers the entirety of the environment. This is not limited to the halal certifier and their applicants, but also involve other agencies such as Ministry of Agriculture, Ministry of Health, Chemistry Department, Ministry of Domestic Trade (Nurulhuda et al., 2012).

\section{Proposing new concept: Halal Food Terrorism (HFT) and Halal Food Defense (HDF)}

Food terrorism has been classified as part of food protection matrix (Spink and Moyer, 2011) and require serious attention for prevention. From previous records, it is clear that food terrorism caused devastating effects in terms of political, economic, and social stability. The Aum Shirikyo and Rajneeshee incidents for instance, had proved that these threats are real. From the halal perspective, the proximate incident that we can highlight here is Malaysia's 2014 Cadbury chocolate incident. Though the exact cause of contamination is unknown or at least several reports have been classified it as crosscontamination (Bernama, 2014), the implication of this incident towards Muslim consumer in Malaysia in terms of social, as well as psychological, political, and economy is obviously outrageous (Nurhafilah, 2016) throughout the nation. This incident is unprecedented in 
Malaysia, and the situation that involved the threat of deliberate contamination, especially food terrorism will be catastrophic if not worse. According to Busta and Kennedy (2011), "intentional contamination of the food system has the potential to result in disastrous and farreaching effects, including direct morbidity and/or mortality, disruption of food distribution, loss of consumer confidence in government and food supply, business failures, trade restrictions and dramatic ripple effects on the economy". Therefore, this indicates that food terrorism will greatly affect the halal ecosystem, its components and its health performance as well.

To apply in the halal ecosystem, the concept of food terrorism must be positioned and fit with the concept of halalan toyyiban. Therefore, we would like to propose a new concept, which is called 'Halal Food Terrorism' (HFT). Before going deeper into the concept, it is useful to understand how the concept of food terrorism can be applied within halalan toyyiban framework. Halalan toyyiban is the central concept of Islamic dietary law (Al-Quran 2:186). The terminology is a combination of two Arabic words of "halal" and "toyyiban". In al-Quran, the word halalan toyyiban is mentioned several times, suggesting that the two components are complimentary. Separately, the word "halal" means permissible; an act, object or conduct over which the individual has freedom of choice and its exercise does not carry either a reward or a punishment (Kamali, 2013). Simply put, it means the religion allowed to do so or to be taken. The opposite of "halal" is "haram" which means prohibited. In term of dietary law, Islam has outlined few features of sources that are prohibited, but the rest that unmentioned (al-Quran or prophetic tradition) is considered permissible as the legal maxim stated: "the origin of everything is permissible unless proven otherwise" (Qaradhawi, 2012). Based on this, we can understand that the concept of "halal" primarily denotes the religious obligation, where every prohibited food sources are clearly and explicitly mentioned in the al-Quran and prophetic tradition.

The second word, though it should not be seen as a separate obligation, is "toyyiban". Toyyiban or toyyib can be defined generally as "good". Based on previous literature, the concept of toyyiban is dynamic and flexible compared to halal concept, where it can be interpreted in various meaning such as nutritious, healthy, high quality, wholesome, clean, pure, or hygienic. The level of toyyib also differs and varying according to Islamic jurisprudence school of thoughts, where Maliki seems to have a broader standard pertaining to victuals (Kamali, 2013). Kamali (2013) also argued that toyyib is all about purity and natural appeal in food selection. In short, halal is the sharia- based element, where toyyiban is more towards the quality-related element, suggesting that these two are complementary with each other in the halalan toyyiban conceptual. Many literature put emphasize that the toyyiban aspect regarded as food safety. Therefore, this leaves a gap in order to relate toyyiban aspect with the concept of food defence. This is because, food safety is a separate concept and has different objective as well as mitigation strategy from food defense, even though both are the key elements under one roof: food protection. Based on this argument, it is clear that there is a necessity for new inclusion for toyyiban so that it applies to the contemporary safe food concept.

According to the studies carried out by Moyer and Spink (2011), Busta and Kennedy (2011) and National Center for Food Protection and Defence (NCFPD), food control system must include two types of food contamination or modification which are unintentional and intentional. A full food control system should have 4 domains which are (i) food quality, (ii) food safety, (iii) food defence and (iv) food security. NCFPD combined domain (ii) and (iii) as part of food protection's core elements (Fredrickson, 2014). Food safety basically deals with unintentional contamination. Unintentional contamination means that the contamination is caused by natural process or accidental. The main objective is to ensure food are safe to eat and free from dangerous levels of harmful infectious and toxic agents (natural and accidental contamination) (Davidson et al., 2017). Food defence is defined by Davidson et al. (2017) as the methodology and countermeasures are taken to prevent and mitigate the effects of intentional incidents and threats to the food chain. This includes what is known as food crime; where food fraud (economically motivated) and food terrorism (ideologically motivated) fall into this category (Davidson et al., 2017).

Based on the food protection framework, halal food protection framework can be established by applying the similar basis, but with slightly different interpretation and meaning. By referring all the cases of halalan toyyiban threats discussed earlier, it shows that it share similar pattern except that halalan toyyiban threats are inclusive of halal hazards or contaminants. Incidents of halalan toyyiban food chain also include the unintentional contamination, such as Cadbury 2014 case, intentional contamination such as economically motivated adulteration (where non-halal substance mixed together with halal product to cut cost). And halal food terrorism. From this point, the 4 domains in the food protection system, we concluded that is the accurate representation of toyyiban aspect. Therefore, we would like to propose a halal food protection framework that includes: halal food assurance and halal food terrorism. 
Furthermore, food terrorism can be described within halalan toyyiban perspective as follows:

Food terrorism can be classified into two categories, the first one named as halal food terrorism. Halal food terrorism is defined as an act of deliberate contamination towards halal food with haram substance such as carrion, blood, swine, unslaughtered halal animal, intoxicant or other impurities with the intention to disrupt social, economy, political stability or otherwise create terror or panic. Toyyiban food terrorism, on the other hand, refers to the conventional food terrorism concept of which the selection of agent which may not explicitly mention in Islamic primary legal sources such as biological, chemical, physical, radio-nuclear and allergens. Halal food terrorism causes disruption towards the political, economy and social stability of Muslim society and above all, it's disrupt spiritual purity in micro-level. In Islam, the relation with the Creator (spirituality) is a virtue, and food can be a factor affecting the spirituality. A hadith from prophetic tradition recorded: "A person travels for a long time in the way of Allah, his hair dishevelled and covered with dust. He lifts his hand towards the sky and makes supplication: "O Lord, O Lord!" However, what he eats is haram, his drink is haram, and his clothes are haram. How can his supplication be accepted since he feeds himself with haram?" (Muslim, Hadith No. 19). The framework of total halal food protection is illustrated in Figure 2.

For toyyiban food terrorism, the implication towards micro-level is political, economy and social stability and for the micro-level, it can cause illness or death. The health performance of halal ecosystem must ensure that both types of food terrorism avoided or mitigated. The affected components include the halal industry, industry player, product and services as well as the consumers. Without mitigation strategy, this threat will become the halal supply chain disruptor. Figure 3 shows the impacts of both halal and toyyiban food terrorism in macro-scale and the micro-scale. The implication of such threats can be described as follows:

\section{a. Disruption of food sources and halal food chain}

Food terrorism activity harming water sources and food can cause a shortage of food. This is because bigscale contamination leads to the limitedness of consumer's necessities. This eventually leads to the food crisis and famine.

\section{b. Harming the consumers' life and safety}

The usage of biological and chemical weapon as a means of attack towards food and agricultural products can cause negative implication towards the consumer. Biological attack on farmed animals in particular, can cause the wide spreading of diseases within the population. For example, the SARS attack on birds resulting death of farmed chicken and infection to human. Another example is the attack of Mad Cow's Disease (BSE) towards the farmed cow and transmitted to human who consumed the infected meat, the attack of Middle East respiratory syndrome coronavirus (MERS$\mathrm{CoV}$ ) towards reared camels which latter transmitted to human (WHO, 2019). This clearly will harm human's health and life at risk.

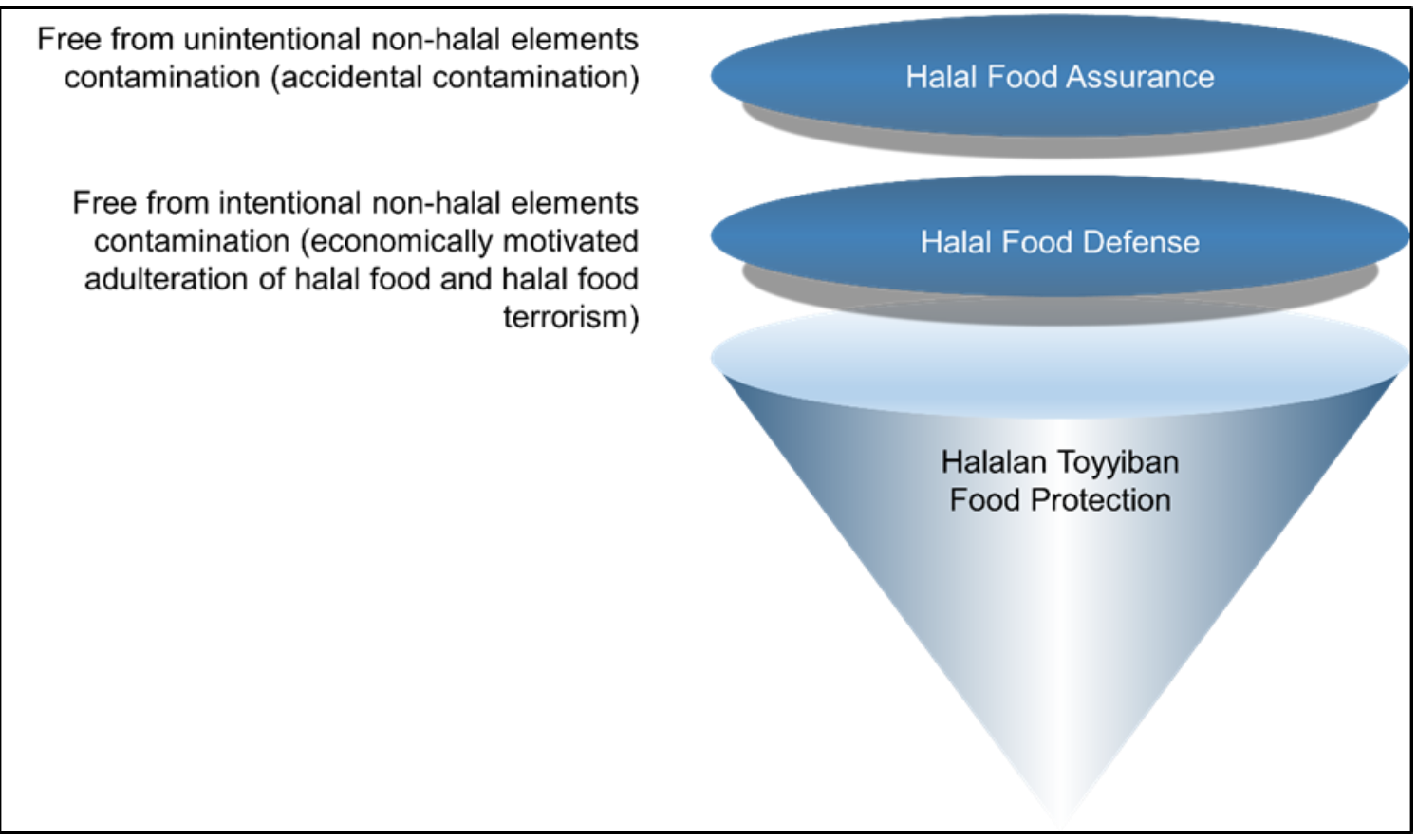

Figure 2. Halalan Toyyiban Food Protection system (Author's analysis based on the National Center for Food Protection and Defense (NCFPD) framework (Fredrickson, 2014)) 


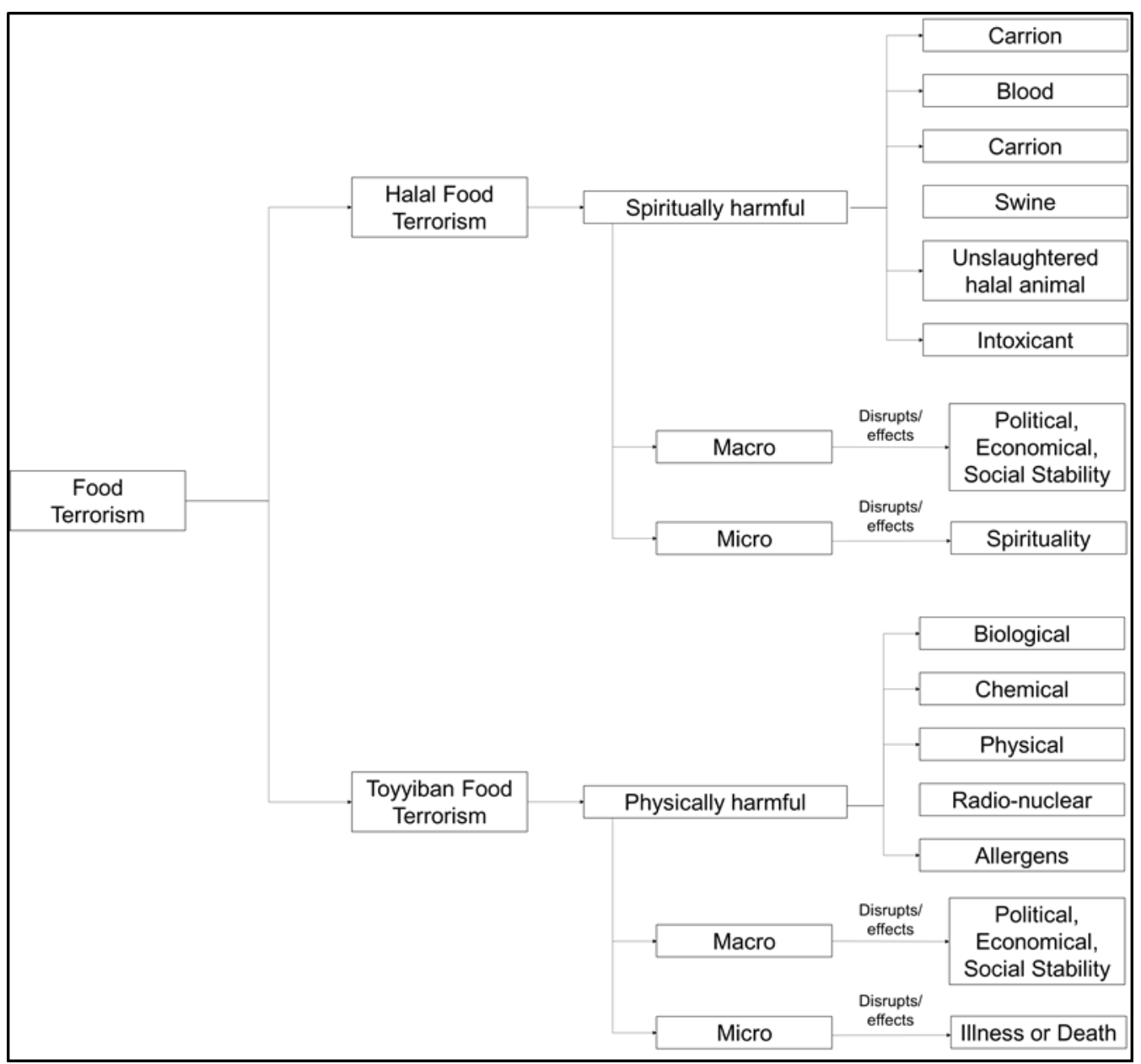

Figure 3. Food terrorism in halalan toyyiban perspective.

\section{c. Altering the status of halal to haram}

Halal and pure food can be changed its status when mixed with haram substance. When a food terrorist attack targeted halal food source, it can alter their status that initially permissible. For example, if it is mixed with an impure substance such as porcine DNA, or harmful elements, the status of food changed to haram.

\section{d. Stir doubtful among consumers towards halal products}

Apart from harmful effects, food crime and terrorism towards a halal product can lead to consumers' hesitation. This is because they lose the trust towards the original product due to contamination with haram and high-risk substance. For instance, the viral attack on the farmed cow with a specific virus can cause a drop of demands for beef supply due to loss of trust. The similar situation when farmed chicken with SARS virus, the demand for fresh chicken meat has dropped because of consumer fear for the risk of infection of the dangerous disease. Therefore, the food producer must not take lightly regarding halal product issue because it can affect trust and belief of consumer towards food products.

\section{e. Damaging the image of halal brand products}

Halal product has its own unique identity in terms of preparation towards the consumer. Hygiene assurance and haram substance-free is the top priority for the halal product. When there are crime and terrorism involved halal food, it will affect their halal status. An attack would likely become questionable for the consumer.

\section{f. Effecting the growth of halal industry}

Halal industry, particularly in Malaysia, has undergone a series of transformation in order to maintain the quality of this industry. In the Eleventh Malaysia Plan (RMK-11) halal industry has been supported and approved by the government. The record shows that RM42 billion worth of halal products exported in 2015 and $9 \%$ of total export contributed by Bumiputera companies. This clearly shows that the halal industry mechanism in Malaysia put effort to maintain and improve its reputation. Nevertheless, with the advancement of technology, halal product also vulnerable to criminal threats as mentioned earlier in this study. This indirectly will interfere with the halal industry stability that affects both and the local and international market.

\section{Conclusion}

The issues highlighted in this study must be resolved with a comprehensive approach. One of the solutions is 
to introduce a specific terminology to address these threats so that the halal food industry is more systematic especially towards food content determination for the benefit of all consumer. All of these threats requires a food protection plan to safeguard "safe food" assurance with the preservation of halal ecosystem in parallel to National Safety Policy and towards the 2050 national transformation plan. Furthermore, this research is carried out to identify the threats of food; crime and terrorism. By that, a comprehensive food protection plan in halalan toyyiban chain should be developed and designed to be fit the Islamic sharia principle.

\section{Acknowledgement}

This research has been made possible with the funding from Ministry of Higher Education Malaysia (MOHE) under research grant FRGS-FP007-2018A, "The Development of Food Defense Model to Address Criminal Threat and Food Terrorism in Halalan Toyyiban Food Chain in Malaysia.

\section{References}

Ali, M.E., Razzak, M.A. and Abd Hamid, S.B. (2014). Multiplex PCR in Species Authentication: Probability and Prospects-A Review. Food Analytical Methods, 7(10), 1933-1949. https:// doi.org/10.1007/s12161-014-9844-4

Ang, S.S., Salleh, A.B., Abu Bakar, F., Yusof, N.A., Abdulamir, A.S. and Lee Y.H. (2010). Risk and health effect of boric acid. American Journal of Applied Sciences, 7(5), 620-627. https:// doi.org/10.3844/ajassp.2010.620.627

Bansal, N., Uppal, V. and Pathak, D. (2011). Toxic effect of formaldehyde on the respiratory organs of rabbits: A light and electron microscopic study. Toxicology and Industrial Health, 27(6), 563-569. https://doi.org/10.1177/0748233710393398

Beck, U. (2002). The Terrorist Threat: World Risk Society Revisited, Theory, Culture and Society, 19 (4), 39-55. https:// doi.org/10.1177/0263276402019004003

Bernama, (2014, May 29). Coklat Cadbury halal - Majlis Fatwa Kebangsaan. Retrieved from Astro Awani website: http://www.astroawani.com/beritamalaysia/coklat-cadbury-halal-majlis-fatwakebangsaan-36793

Caldasa, M.M. and Perz, S. (2013). Agro-Terrorism? The Causes and Consequences of The Appearance of Witch's Broom Disease in Cocoa Plantations of Southern Bahia, Brazil, Geoforum, 47, 147-157. https://doi.org/10.1016/j.geoforum.2013.01.006

Carus, W.S. (2001). Bioterrorism and Biocrimes: The
Illicit Use of Biological Agents Since 1900., p 181182. Washington: Center for Counterproliferation Research. https://doi.org/10.21236/ADA402108

Castle, S. (2013, February 19). Nestle Remove 2 Products in Horse Meat Scandal. Retrieved from The New York Times website: http:// www.nytimes.com/2013/02/20/world/europe/nestlepulls-2-products-in-horse-meat-scandal.html? $\mathrm{r}=0$ andpagewanted $=$ print.

CATRC. (2010). The Counter Agro Terrorism Research Center. Retrieved on October 20, 2019 from CATRC Website: http://catrc.realdesign.co.il/

Chuah, L.-O., He, X.B., Effarizah, M.E., Syahariza, Z.A., Shamila-Syuhada, A.K. and Rusul, G. (2016). Mislabelling of beef and poultry products sold in Malaysia. Food Control, 62, 157-164. https:// doi.org/10.1016/j.foodcont.2015.10.030

Dalziel, G.R. (2009). Food Defence Incidents 19502008: A Chronology and Analysis of Incidents Involving the Malicious Contamination of The Food Supply Chain. Singapore: Nanyang Technological University.

Das, S. and Kataria, V.K. (2010). Bioterrorism: A Public Health Perspective. Medical Journal Armed Forces India, 66(3), 255-260. https://doi.org/10.1016/S0377 $-1237(10) 80051-6$

Davidson, R.K., Antunes, W., Madslien, E.H., Belenguer, J., Gerevini, M., Perez, T.T. and Prugger, R. (2017). From food defence to food supply chain integrity. British Food Journal, 119(1), 52 - 66. https://doi.org/10.1108/BFJ-04-2016-0138

Ereifej, K.I. (2011). Establishing Database for Food Products and Ingredients to Strengthen Readiness in Food Terrorism Attack. In Hefnawy, M. (Ed.) Advances in Food Protection Focus on Food Safety and Defense, p. 137-153. Netherlands: Springer. https://doi.org/10.1007/978-94-007-1100-6_8

Everstine, K. Spink, J. and Kennedy, S. (2013). Economically motivated adulteration (EMA) of food: common characteristics of EMA incidents. Journal of Food Protection, 76(4), 723-735. https:// doi.org/10.4315/0362-028X.JFP-12-399

Food Act 1983 (Act 281) and Regulations (Malaysia). (2018). (MY).

Fredrickson, N.R. (2014). Food Security: Food Defense and Biosecurity. In Van Alfen, N.K. (Eds). Encyclopedia of Agriculture and Food Systems, p. 311-323. San Diego: Elsevier. https:// doi.org/10.1016/B978-0-444-52512-3.00036-X

Hansen, C. (2010). An Exploration of Potential Chemical and Biological Threat Agents. In Koukouliou, V., Ujevic, M. and Premstaller, O. (Eds). Threats to 
Food and Water Chain Infrastructure, p. 14-24. Netherlands: Springer, Dordrecht. https:// doi.org/10.1007/978-90-481-3546-2_2

Hishamuddin, A. (2007). Community Participation and Empowerment: An Approach for JAKIM Halal Verification and Feedback Mechanism. Shah Alam: Universiti Teknologi MARA, MSc. thesis.

Jeyaletchumi, P. (2003). Detection of Beta-agonist Residues in Meat Using Enzyme Linked Immunosorbent Assay and Gas Chromatography Mass spectrometry. Serdang: Universiti Putra Malaysia, MSc. thesis.

Johnson, R. (2014). Food Fraud and "Economically Motivated Adulteration" of Food and Food Ingredients. United States: (CRS Report) Congressional Research Service.

Kamali, M.H. (2013). The Parameters of Halal and Haram in Shariah and the Halal Industry. Kuala Lumpur: The International Institute of Islamic Thought.

Kartheek, M., Smith, A.A., Muthu, K.A. and Manavalam, R. (2011). Determination of Adulterant in Food: A Review. Journal of Chemical and Pharmaceutical Research, 3(2), 629-636.

Kinsey, J., Stinson, T., Degeneffe, D., Ghosh, K. and Busta, F. (2009). Consumer Response to a New Food Safety Issue. In Barbosa-Canovas, G., Mortimer, A. and Lineback, D. (Eds). Food Terrorism, Global Issues in Food Science and Technology, p 145-164. Oxford,UK: Elsevier Inc. https://doi.org/10.1016/ B978-0-12-374124-0.00010-7

Kumarappa, O.K.M. (2018) Cacing dalam tin sardin. Retrieved on December 20, 2019 from Berita Harian website: https://www.bharian.com.my/berita/ kes/2018/06/442271/cacing-dalam-tin-sardin

Lister, S.A. and Becker, G.S. (2009). Bovine Spongiform Encephalopathy (BSE, or 'Mad Cow Disease'): Current and Proposed Safeguards. New York: Nova Science Publishers Inc.

Manning, L. (2019). Food defence: Refining the taxonomy of food defence threats. Trends in Food Science and Technology, 85, 107-115. https:// doi.org/10.1016/j.tifs.2019.01.008

Manning, L., Smith, R. and Soon, J.M. (2016). Developing an Organizational Typology of Criminals in The Meat Supply Chain. Food Policy, 59, 44-54. $\quad$ https://doi.org/10.1016/ j.foodpol.2015.12.003

Mitenius, N., Kennedy, S.P. and Busta, F.F. (2014). Food Safety Management. London: Academic Press.

Moore, J.F. (1999). The Death of Competition: Leadership and Strategy in the Age of Business
Ecosystems. New York: Harper Business.

Muhamad Afiq, A.R. and Mohd Anuar, R. (2018). Aplikasi Umum Al-Balwa Dalam Menangani Pencemaran Silang Produk Makanan. In Zahari Mahad, M. and Dina, I.S. (Eds). Isu-isu Semasa Islam dan Sains, p. 491-507. Bandar Baru Nilai: Penerbit USIM.

Ni'mah, A., Kartikasari, Y., Pratama, A.D., Kartikasari, L.R., Hertanto, B.S. and Cahyadi, M. (2016). Detection Of Pork Contamination In Fresh And Cooked Beef Using Genetic Marker MitochondrialDna Cytochrome B By Duplex-PCR. Journal of the Indonesian Tropical Animal Agriculture, 41(1), 712. https://doi.org/10.14710/jitaa.41.1.7-12

Nurhafilah, M., Muslim, N., Che Omar, M.F. and Husin, A. (2016). The Cadbury Controversy: Blessings in Disguise? In Ab. Manan, S.K., Abd Rahman, F. and Sahri, M. (Eds). Contemporary Issues and Development in the Global Halal Industry, p. 95104. Singapore: Springer. https:// doi.org/10.1007/978-981-10-1452-9_9

Nurulhidayah A.F., Che Man, Y., Mohammad Aizat, J. and Suhaimi A.R. (2012). The Contribution of Science and Technology in Determining the Permissibility (Halalness) of Food Products. Revelation and Science 2(1), 1-9.

Nurulhuda, N., Nor Laila, M.N. and Zainal, S. (2014). Strategic Approach to Halal Certification System: An Ecosystem Perspective. Procedia - Social and Behavioral Sciences, 121,79-95. https:// doi.org/10.1016/j.sbspro.2014.01.1110

Pedersen, B., Gorzkowska-Sobas, A.A., Gerevini, M., Prugger, R., Belenguer, J., Maletti, M., Ljønes, M., Gilljam, B.H., Tønsager, J., Opstad, A.M. and Davidson, R.K. (2016). Protecting our food: Can standard food safety analysis detect adulteration of food products with selected chemical agents? Trends in Analytical Chemistry, 85(B), 42-46. https:// doi.org/10.1016/j.trac.2016.05.014

Qaradhawi, M.Y. (2012). Al-halal wa al-haram fi alIslam. Cairo: Maktabah Wahbah.

Rohn, E. and Erez, G. (2013). Framework For AgroTerrorism Intentions Detection Using Overt Data Sources. Technological Forecasting and Social Change, 80(9), 1877-1884. https://doi.org/10.1016/ j.techfore.2013.06.008

Spink, J. and Moyer, D.C. (2011). Defining the Public Health Threat of Food Fraud. Journal of Food Science, 76(9), 157-163. https://doi.org/10.1111/ j.1750-3841.2011.02417.x

Tucker, J.B. (2002). A Farewell to Germs: The U.S. Renunciation of Biological and ToxinWarfare 1969- 
1970. International Security, 27(1) 107-148. https:// doi.org/10.1162/016228802320231244

United States Food and Drug Administration (FDA). (2019). Food Safety Modernatization Act (FSMA). Retrieved on December 20, 2019 from FDA Website: https://www.fda.gov/food/guidanceregulation-food-and-dietary-supplements/food-safety -modernization-act-fsma

White, S.G. (2009). It Happened Here: Biological Terrorism in the United States, A New Understanding of Terrorism: Case Studies, Trajectories and Less. New York: Springer. https:// doi.org/10.1007/978-1-4419-0115-6_5

World Health Organization (WHO) (2019). Factsheets Mers-cov. Retrieved on December 20, 2019 from WHO Website: http://www.who.int/mediacentre/ factsheets/mers-cov/en/

Yusof, M.F. and Suhaini, N.A. (2019). Penemuan cecair hijau di hulu Sungai Kim Kim pula. Retrieve on December 20, 2019 from Berita Harian Website: https://www.bharian.com.my/berita/ nasional/2019/06/578506/penemuan-cecair-hijau-dihulu-sungai-kim-kim-pula 